\title{
Klasifikasi SMS Center RSUD SMART Berdasarkan Jenis Keluhan Pelayanan Menggunakan TS Smoothing
}

\author{
Sholeh Rachmatullah, Teknik Informatika Universitas Madura, Esther Irawati Setiawan, Teknologi \\ Informasi Institut Sains dan Teknologi Terpadu Surabaya, Reddy Alexandro Harianto, Informatika \\ Institut Sains dan Teknologi Terpadu Surabaya
}

\begin{abstract}
Abstrak - RSUD SMART memiliki layanan SMS Center yang digunakan untuk berinteraksi dengan masyarakat dalam menerima pertanyaan, masukan, saran dan kritik maupun pengaduan. Informasi yang diterima dalam bentuk SMS hanya disimpan dan tidak dikelompokkan berdasarkan unit atau layanan yang dituju sehingga pihak manajemen rumah sakit tidak bisa mengukur tingkat pelayanan di tiap unit. Penelitian ini melakukan klasifikasi terhadap data SMS dan saran responden dari masyarakat yang ditujukan kepada Direktur Rumah Sakit. Data SMS yang diklasifikasi berasal dari database aplikasi SMS Center RSUD SMART Pamekasan. Data SMS dan saran responden diklasifikasikan dalam 10 kelas yaitu Rawat Inap, Rawat jalan, Laboratorium, Farmasi, BPJS, Humas, Loket Pembayaran, Sarana dan Prasarana, Profesi dan tidak Terklasifikasi, serta melakukan scoring SMS. Sebelum melakukan proses klasifikasi terlebih dahulu dilakukan preprocessing seperti penyamaan karakter, penghapusan tanda baca, mengembalikan singkatan, terjemah bahasa daerah (Bahasa Madura), penghapusan angka, penghapusan kata yang tidak penting dalam SMS, dan stemming untuk mengubah kata menjadi kata dasar. Penelitian ini menggunakan algoritma Naive Bayes dengan Two Stage (TS) Smoothing. Dalam beberapa uji coba yang telah dilakukan terhadap 2292 data dengan presentase data traning sebesar $20 \%, 30 \%, 40 \%$ dan $50 \%$ mendapatkan rata-rata akurasi sebesar $82,97 \%$ dengan nilai $\lambda=0.2, \mu=2000$ dan threshold=3. Bahkan dalam salah satu uji coba klasifikasi dengan threshold statis mencapai akurasi $86,73 \%$ sedangkan akurasi terendah dengan threshold dinamis mencapai $\mathbf{7 4 , 2 8 \%}$. Pengaturan threshold statis terbukti meningkatkan akurasi klasifikasi sebesar $6,14 \%$.
\end{abstract}

Kata Kunci: SMS Center, klasifikasi, Naive Bayes, TS Smoothing

\section{PENDAHULUAN}

CMS Center merupakan layanan SMS gateway yang digunakan oleh RSUD dr. H. Slamet Martodirdjo (SMART) kabupaten Pamekasan untuk berinteraksi dengan

13 Juni 2019, RSUD SMART

Sholeh Rachmatullah, Teknik Informatika, Universitas Madura, Pamekasan, Jawa Timur, Indonesia (e-mail: sholeh@unira.ac.id)

Esther Irawati Setiawan, Teknologi Informasi, Institut Sains dan Teknologi

Terpadu Surabaya, Surabaya, Jawa Timur, Indonesia (e-mail: esther@stts.edu)

Reddy Alexandro Harianto, Informatika, Institut Sains dan Teknologi

Terpadu Surabaya, Surabaya, Jawa Timur, Indonesia (e-mail: reddy@ stts.edu) masyarakat menggunakan fasilitas SMS berupa pertanyaan, masukan, saran, kritik maupun pengaduan dari masyarakat, dan digunakan sebagai media untuk menyampaikan SMS di lingkup penanggung jawab unit. Informasi berupa SMS yang diterima dalam dua tahun hanya disimpan dalam data base dalam jumlah besar dan tidak terklasifikasi secara khusus.

Hal ini menyebabkan petugas kesulitan menghitung statistik keluhan masyarakat berdasarkan isi pesan singkat di setiap tahunnya. Penulis berusaha untuk mengklasifikasikan data SMS tersebut ke dalam multi class [1] berdasarkan ruang lingkupnya [2] dan hasilnya dapat dipergunakan oleh pihak manajemen untuk melakukan evaluasi di setiap unit serta proyeksi pengembangan Sumber Daya Manusia. Salah satu keluaran dari hasil klasifikasi misalnya dengan memberikan surat rekomendasi berupa surat Evaluasi Internal RSUD SMART terhadap unit pelayanan yang mendapatkan skor tertinggi dari laporan yang diterima melalui SMS Center [3].

Terdapat 4 jenis teknik smoothing [4], [5] di dalam penggunaan metode Nä̈ve Bayes untuk proses klasifikasi teks. Teknik tersebut adalah Jelinek-Mercer (JM) smoothing, Dirichlet (Dir) smoothing, Absolute Discounting (AD) smoothing, dan Two-Stage (TS) smoothing. Dari hasil penelitian tersebut diperlihatkan bahwa metode smoothing mampu meningkatkan tingkat akurasi dari Nä̈ve Bayes untuk proses klasifikasi teks.

Untuk memaksimalkan performa dari Nä̈ve Bayes Clasification [6] dalam penelitian ini penulis menggunakan Two-Stage Smoothing. Two-Stage Smoothing digunakan karena dikenal dengan akurasi dan kecepatan dalam proses klasifikasi teks dibandingkan dengan tanpa menggunakan smoothing atau hanya mengandalkan Naive Bayes untuk mengklasifikasikan SMS [3]. Metode ini digunakan untuk menyelesaikan permasalahan multi labeling [7], [8], [9] dan multi klasifikasi yang disesuaikan dengan pola atau model data input yang ada dalam sistem sebelumnya.

\section{TINJAUAN PUSTAKA}

Text Classification harus melalui beberapa tahapan yang harus dilakukan secara berurutan mulai dari awal atau input sampai dengan outputnya. Hal tersebut disebabkan karena masing-masing tahapan memiliki keterkaitan antara satu 
dengan yang lainnya. Tahapan-tahapan dalam Klasifikasi teks tersebut memiliki tujuan untuk mengetahui pola dokumen yang diolah.

\section{A. Tahapan Klasifikasi}

Tahapan-tahapan dalam klasifikasi teks tersebut adalah sebagai berikut:

1. Tahapan Tokenizing. Pada tahap ini string input dipotong menurut setiap kata yang menyusunnya.

2. Tahapan Filtering. Tahapan ini merupakan kelanjutan tahapan tokenizing dimana kata-kata penting yang dihasilkan pada tahapan tokenizing diambil untuk disaring menggunakan dua metode yaitu stop list yang artinya membuang kata yang kurang penting, ataupun dengan metode word list yang artinya menyimpan kata penting. Kedua metode ini berfungsi untuk menyimpan kata yang dianggap penting. Tahapan ini sangat penting mengingat sebuah dokumen sering menggunakan kata penghubung.

3. Tahapan Stemming. Pada tahapan ini kata dasar atau akar kata yang berasal dari hasil filtering dicari, adalah tahap dimana mencari akar kata dari tiap kata hasil filtering, misalkan dengan membuang imbuhan yang ada pada kata tersebut. Proses ini mengguakan algoritma ECS [2], pengembangan dari Confix Stemmer [10].

4. Tahapan Tagging. Tahapan ini berfungsi untuk mencari bentuk awal dari tiap kata lampau dari hasil stemming. Bedanya tahapan ini tentu saja tidak dilakukan untuk teks Bahasa Indonesia yang tidak mengenal istilah kata lampau.

5. Tahap Analyzing. Tahapan ini merupakan tahap penentuan seberapa jauh keterhubungan antar kata dengan dokumen yang ada. Tahapan klasifikasi lihat Gambar 1.

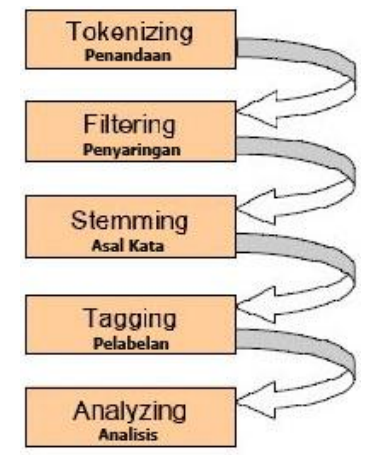

Gambar 1. Tahapan Text Classification.

\section{B. Algoritma Naive Bayes dan Smoothing}

Algoritma Nä̈ve Bayes [6] merupakan pengklasifikasian dengan metode probabilitas dan statistik yang dikemukakan oleh ilmuwan Inggris Thomas Bayes, yaitu memprediksi peluang di masa depan berdasarkan pengalaman di masa sebelumnya sehingga dikenal sebagai teorema Bayes. Naïve Bayes sendiri menggunakan kemiripan fitur antara data training dan data testing dimana nantinya akan diambil class yang paling mirip dari data training tersebut. Berdasarkan beberapa penilaian, algoritma ini dikenal sebagai algoritma yang sederhana, cepat dan berakurasi tinggi. Nä̈ve Bayes diasumsikan setiap atribut saling bebas, maka persamaan yang didapatkan adalah sebagai berikut:

$$
P(c \mid d)=\frac{P(d \mid c)}{P(c)+P(d)}
$$

Dimana c adalah sebuah kelas, $d$ adalah sebuah dokumen. Setiap peluang pada masing-masing kelas akan dikalikan dan akan menghasilkan nilai Naïve Bayes pada masing-masing rumus tersebut. Nilai tertinggi pada klasifikasi ini akan menjadi hasil klasifikasi dari Nä̈ve Bayes tersebut. Berikut adalah rumusnya:

$$
\begin{gathered}
C_{\text {map }}=\max _{c \in C} \hat{P}(c \mid d)=\max _{c \in C} \hat{P}(c) \prod_{1 \leq k \leq n d} P\left(t_{k} \mid c\right) \\
\hat{P}(c)=\frac{N(c)}{N}
\end{gathered}
$$

Dimana $\hat{P}(c \mid d)$ adalah estimasi probabilitas Kategori $c$ terhadap dokumen $d, \hat{P}(c)$ adalah estimasi probabilitas prior dari dokumen muncul di kateori $c, P\left(t_{k} \mid c\right)$ adalah probabilitas bersyarat dari term $t_{k}$ yang muncul di kategori $c$.

Smoothing untuk NBC ini mengacu pada penyesuaian estimator maksimum likelihood untuk model bahasa sehingga akan lebih akurat. Smoothing sendiri tidak diperlukan untuk menetapkan nilai nol untuk kata yang tak terlihat. Smoothing memainkan dua peran penting yaitu meningkatkan akurasi model bahasa. serta mengakomodasi generasi pada umumnya dan kata noninformatif. Generator kemungkinan maksimum umumnya di bawah perkiraan probabilitas dari kata yang tak terlihat. Jadi tujuan utama smoothing adalah untuk memberikan probabilitas tidak nol untuk kata-kata yang tak terlihat dan meningkatkan akurasi probabilitas estimator.

Untuk menghindari nilai 0 pada hasil perhitungan probabilitas bersyarat dari term tertentu yang muncul di sebuah kategori diperlukan metode smoothing [5]. Beberapa metode smoothing yang dapat dilakukan, tetapi dari penelitian sebelumnya terdapat beberapa metode smoothing yang sudah diujicobakan pada Naïve Bayes meliputi [4] :

1. Laplace Smoothing.

$$
p\left(w \mid c_{i}\right)=\frac{1+c\left(w, c_{i}\right)}{|V|+\sum_{w \prime} \in V c\left(w^{\prime}, c_{i}\right)}
$$

2. Two-Stage (TS) Smoothing, merupakan kombinasi antara Dirichlet Smoothing dengan metode interpolation.

$$
p_{\lambda, \mu}\left(w \mid c_{i}\right)=(1-\lambda) \frac{c\left(w, c_{i}\right)+\mu p(w \mid C)}{\sum_{w^{\prime} \in V} c\left(w^{\prime}, c_{i}\right)+\mu}+\lambda p(w \mid C)
$$

Modifikasi ini didasarkan pada penggunaan persamaan rumus laplace dan Two Stage Smooting menjadi seperti dibawah ini:

$$
p_{\lambda, \mu}\left(w \mid c_{i}\right)=(1-\lambda) \frac{1+c\left(w, c_{i}\right)+\mu p(w \mid C)}{\sum_{w^{\prime} \in V} c\left(w^{\prime}, c_{i}\right)+\mu}+\lambda p(w \mid C)
$$

Modifikasi dilakukan jika pada saat perhitungan nilai probabilitas dengan menggunakan persamaan rumus TwoStage Smooting sudah ditentukan dan kata unik hasil stemming tidak ada di dalam semua basis data training maupun di dalam basis data training kelas itu sendiri.

\section{Multi Klasifikasi Teks}

Kategorisasi dokumen teks secara multi-label adalah masalah yang berperan penting dalam sistem temu kembali informasi. Klasifikasi multi-label berbeda dengan klasifikasi single label. Klasifikasi single label akan mengklasifikasikan suatu dokumen ke dalam satu kategori dokumen saja. Sedangkan klasifikasi multi-label dapat mengelompokkan suatu dokumen ke lebih dari satu kategori. Sebagai contoh, sebuah artikel ilmiah yang di dalamnya membahas secara rinci 
mengenai deteksi dini kanker ovarium dengan pendekatan bioinformatika dapat memiliki lebih dari satu label dokumen yaitu: kesehatan, bioinformatika dan wanita.

Untuk mengklasifikasikan artikel ke dalam multi label [7], dilakukan pendekatan dengan mentransformasikan klasifikasi multi label menjadi beberapa kasus klasifikasi single label [6]. Dengan melakukan transformasi single label maka tiap-tiap data dilakukan pengecekan terhadap semua label yang ada. Pengecekan yang dilakukan akan menentukan apakah data tersebut "termasuk" atau "tidak termasuk" pada suatu label. Hal ini kurang efisien karena memerlukan waktu komputasi yang cukup lama untuk mengecek suatu dokumen ke semua label. Metode ini tidak memperhitungkan korelasi antara label yang satu dengan label yang lain.

Penentuan multi klasifikasi dilakukan dengan dua cara yaitu dengan memberikan nilai threshold statis dan nilai threshold dinamis. Cara kerja multi klasifikasi mengambil 2 nilai probabilitas tertinggi dari kelas tertentu, hal ini dilakukan untuk menentukan apakah dokumen tersebut hanya tergolong single classification atau multi classfication. Pada penentuan multi klasifikasi dengan nilai threshold statis, sistem akan menetapkan nilai threshold yang diinput secara statis, kemudian melakukan perbandingan selisih antara nilai threshold yang sudah ditentukan dengan nilai probabilitas terbesar kedua. Jika nilai threshold lebih besar dari nilai probabilitas terbesar kedua maka program akan menjadikan probabilitas kelas tersebut sebagai dokumen multi kelas. Ketika nilai threshold lebih kecil atau sama dengan nilai probabilitas terbesar kedua, maka dokumen tersebut hanya memiliki single classification.

Pada penentuan multi classification [9] dengan nilai threshold dinamis, maka setiap dokumen yang diuji coba akan memiliki nilai threshold yang berubah-ubah tergantung pada jarak antar probabilitas kelas yang satu dengan probabilitas kelas lainnya. Cara kerja dari konsep ini adalah jika jarak nilai probabilitas kedua terbesar dengan nilai probabilitas terbesar pertama lebih dominan dari pada nilai probabilitas kelas lainnya terhadap nilai probabilitas pertama, maka probabilitas kelas tersebut merupakan bagian dari kelas probabilitas terbesar pertama yang berarti dokumen tersebut terdeteksi sebagai multi klasifikasi. Namun jika jaraknya tidak lebih dominan dari pada kelas lainnya maka dokumen diklasifikasikan ke dalam satu kelas saja [11].

\section{Metodologi PENELITIAN}

Penelitian ini meimiki input utama yaitu data SMS yang masuk atau diterima pada database aplikasi SMS Center RSUD dr. H. Slamet Martodirdjo Kabupaten Pamekasan dan form isian komentar responden hasil survei kepuasan masyarakat selama 4 bulan yang dilakukan dalam kurun waktu bulan Mei dan Juni tahun 2015 untuk tahap pertama, kemudian pengambilan data responden tahap ke dua pada bulan Oktober dan Nopember tahun 2015 oleh oleh LP3M Akademi Keperawatan Pemerintah Kabupaten Pamekasan dengan total keseluruhan yaitu 2292 data dan 415 data yang termasuk multi label klasifikasi. Sistem ini bersifat multi-class dimana setiap SMS yang diterima akan masuk ke salah satu atau lebih kelas yang selanjutnya akan diteruskan ke penanggungjawab unit terkait yang disesuaikan dengan hasil klasifikasi oleh aplikasi.

Beberapa data SMS yang tersimpan dalam database Aplikasi SMS RSUD Pamekasan terdiri dari nomor urut, nomor pengirim, waktu diterimanya SMS (jam, tanggal, bulan dan tahun) teks SMS, isi pesan SMS dan jenis teks. Dalam proses klasifikasi data yang digunakan hanya teks SMS sehingga diperlukan dilakukan proses cleaning dengan mengambil data teks SMS saja, sedangkan nomor pengirim, waktu diterimanya SMS boleh diabaikan hal ini karena tidak berpengaruh terhadap proses selanjutnya. Sedangkan form isian komentar responden hasil survei kepuasan masyarakat selama 4 bulan pada bulan Mei, Juni, Oktober dan Nopember tahun 2015 oleh LP3M Akademi Keperawatan Pemerintah Kabupaten Pamekasan, ini merupakan hasil kerjasama dengan pihak RSUD yang dilakukan hanya dalam 1 tahun saja atau tidak rutin. Formulir yang berasal dari masyarakat berisikan form isian no responden, lokasi ruangan, nama, alamat asal, jenis kelamin, pendidikan, pekerjaan, usia, tanggal, status pemeriksaan, hari rawat ke, jawaban pilihan ganda dan saran responden. Data responden yang akan di masukkan ke dalam sistem aplikasi ini adalah hanya data saran responden dan proses pelabelan setiap isian data saran dari responden.

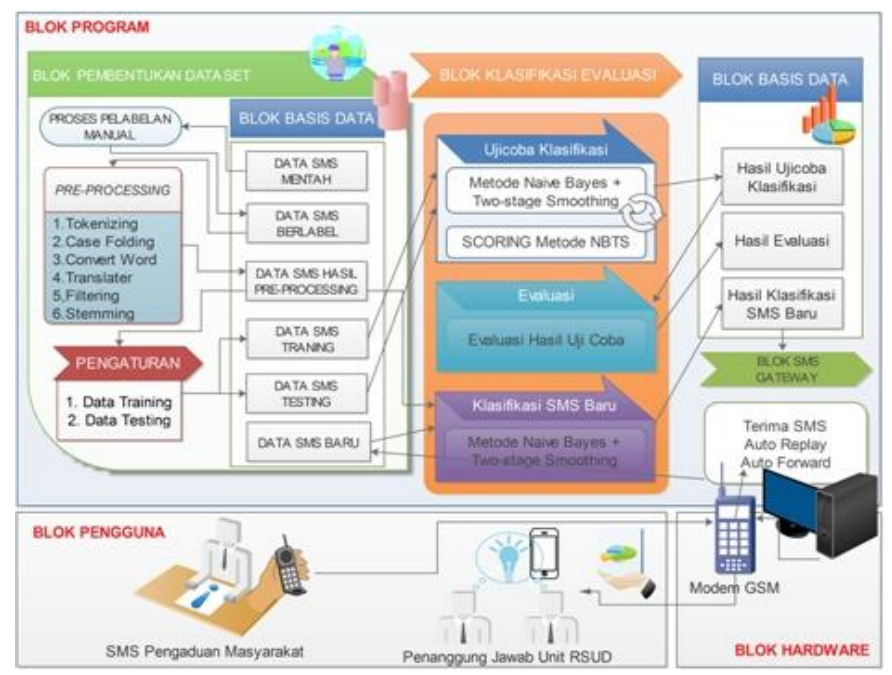

Gambar 2. Arsitektur Sistem

Dalam penelitian ini data SMS dan saran responden diklasifikasikan ke dalam dalam sepuluh kelas antara lain Humas, Sarana dan Prasarana, Laboratorium, Farmasi, Rawat Inap, Rawat Jalan, Loket Pembayaran, BPJS, Profesi dan Tidak Terklasifikasi. Kelas Tidak Terklasifikasikan diperuntukkan untuk SMS yang sifatnya tidak spesifik mengarah ke sembilan kelas yang sudah disebutkan di atas, misalnya SMS Spam yang bersal dari orang yang tidak bertanggungjawab, [12] SMS Iklan yang berisikan berbagai promosi layanan atau penjualan dari orang lain, dan SMS Operator merupakan informasi yang dikirimkan oleh operator penedia jaringan kartu selular, biasanya SMS yang diterima dari operator memiliki nomor khusus empat sampai enam digit nomor pengirim. 
Klasifikasi tersebut dimaksudkan untuk mendistribusikan SMS ke masing-masing unit agar ditangani dan dijadikan bahan monitoring dan evaluasi unit tersebut. Setiap SMS yang masuk diproses untuk mengetahui kecocokan data dengan salah satu atau lebih kelas yang tersedia. SMS baru yang diterima oleh SMS Gateway akan proses sistem, sistem mengolah data SMS dengan melakukan pre-processing dan melakukan proses klasifikasi sehingga menghasilkan multi kelas, kemudian aplikasi akan meneruskan pesan SMS tersebut kepada unit yang dituju berdasarkan hasil klasifikasi. Selain unit, pihak manajemen rumah sakit juga dapat memonitoring dan mengevaluasi kinerja pelayanan dengan lebih mudah. Dari hasil klasifikasi setiap periode tertentu, sistem akan memberikan rekomendasi berupa surat pemberitahuan terhadap unit yang memiliki skoring tertinggi berdasarkan laporan dari data SMS Center. Model klasifikasi yang dibangun akan dijabarkan secara menyeluruh dalam suatu sistem yang terstruktur yang disajikan pada Gambar 2 .

Membangun arsitektur sistem untuk mempermudah kerangka kerja sistem yang akan dikerjakan, dalam hal ini dilakukan pemisahan blok untuk program, hardware dan pengguna. Pada Gambar 2 arsitektur sistem bagian BLOK PROGRAM merupakan bagian dari sistem perangkat lunak yang berfungsi untuk melakukan pengolahan dan pemrosesan data. BLOK PROGRAM memiliki 4 sub blok diantaranya Blok Pembentukan Data Set, Blok Basis Data, Blok Klasifikasi Evaluasi, dan Blok SMS Gateway.

Proses awal ditunjukkan dalam Blok Pembentukan Data Set, ada 3 proses yang dilakukan yaitu proses pelabelan secara manual pada data SMS mentah, Pre-Processing, dan pengaturan data testing serta training. Pada proses PreProcessing ada tahapan stemming yang menggunakan algoritma Enhanced Confix Stripping (ECS) Stemmer [13]. Pada Blok Basis Data mempunyai 9 jenis data yaitu data SMS mentah, SMS berlabel, SMS hasil pre-processing, SMS trainig, SMS testing, hasil uji coba klasifikasi, hasil evaluasi, SMS baru, dan hasil klasifikasi SMS baru.

Blok Klasifikasi Evaluasi terdiri dari 3 proses yaitu proses pertama yaitu Uji Coba Klasifikasi berfungsi untuk melakukan perhitungan menggunakan metode Naive Bayes dengan TwoStage Smoothing (NBTS) [4] dan Scoring. Scoring menggunakan metode NBTS untuk menghitug skor masing masing dokumen agar diketahui tingkat keluhan yang ada. Tingkat keluhan dibagi menjadi tiga yaitu ringan dengan skor 1, sedang dengan skor 3, dan tinggi dengan skor 5. Nilai rata rata skor diperoleh dari jumlah dokumen dengan total skor dibagi 2. Selanjutnya proses kedua Evaluasi berfungsi menganalisa hasil uji coba klasifikasi agar sesuai harapan penelitian, dan proses ketiga Klasifikasi SMS Baru berfungsi untuk mengklasifikasikan data SMS baru yang diterima dari blok SMS gateway. BLOK HARDWARE berfungsi sebagai SMS gateway yang bertugas untuk menerima SMS, dan auto respon $S M S$.

$$
\text { Score Total }=\frac{\sum \text { Dokumen }+\sum \text { Score dokumen }}{2}
$$

Fungsi dari proses perhitungan NBTS dalam melakukan proses klasifikasi teks yang bersifat multi kelas dibedakan berdasarkan penentuan nilai threshold statis dan nilai threshold dinamis. Proses perhitungan fungsi Naive Bayes dengan Two Stage Smoothing terhadap setiap kelasnya akan menghasilkan nilai probabilitas NBTS setaiap kelas. Setelah itu carilah 2 angka nilai maksimum dari keseluruhan kelas, kemuadian ambillah 2 nilai terbesar dari nilai probabilitas NBTS, langkah selanjutnya adalah menentukan nilai threshold dengan nilai statis atau dinamis.

Nilai maksimun terhadap suatu fungsi akan dipilih sebagai hasil keputusan. Hasil keputusan bisa menunjukkan data SMS tersebut tergolong dalam satu kelas atau maksimal dua kelas. Dalam menentukan hasil klasifikasi bersifat multi kelas atau tidak maka dibuatlah pendekatan penyelesaian dengan menggunakan batasan atau threshold. Threshold berfungsi untuk mengukur apakah nilai Naive Bayes Classification Two Stage (NBCTS) maksimum ke 2 merupakan bagian dari nilai Naive Bayes tertinggi ke 1. Jika nilai Naive Bayes lebih besar dari nilai threshold yang ditentukan maka hasil klasifikasinya hanya memiliki satu kelas saja, jika nilai Naive Bayes terbesar ke 2 lebih kecil atau sama dengan nilai threshold maka hasil klasifikasinya memiliki dua kelas atau multi kelas.

Pengaturan nilai threshold ada dua cara, yang pertama adalah threshold statis artinya penentuan nilai threshold ditentukan oleh user dan bersifat tetap atau tidak berubah ketika diuji cobakan terhadap setiap teks, sedangkan yang ke dua adalah threshold dinamis dengan penentuan nilai threshold bergantung pada rata-rata nilai probabilitas kelas di setiap proses klasifikasinya sehingga sifat threshold ini selalu berubah atau selalu berbeda disetiap teks yang di klasifikasikan.

\section{Algoritma 1. Klasifikasi NBTS Threshold Statis}

[Fungsi : menghitung nilai probabilitas teks]

[input : hasil stemming teks data training dan testing]

[output : klasifikasi kelas]

1: Lakukan proses pre-processing [tokenizing, casefolding, convert word, translater, filtering, stemming]

2: Tentukan koefisien kontrol $\mu$ (miu), $\lambda$ (lamda), threshold dan modifikasi rumus.

3: Hitung prior probability naive bayes semua kelas.

4: Menghitung nilai probalitias Two Stage Smoothing setiap kata terhadap semua kelas.

5: Hitung nilai probabilitas setiap kelas.

6: Lakukan normalisasi.

7: Sorting nilai probabilitas kelas.

8: Ambil 2 nilai probabilitas tertinggi.

9: Periksalah nilai probabilitas tertinggi ke 2. Jika nilainya lebih besar dari threshold maka output satu kelas, tetapi jika nilainya lebih kecil dari dari threshold maka outputnya multi kelas.

Contoh SMS dengan menggunakan algoritma 1, dengan teks awal "Kami keluarga pasen rsud pamekasan, kami merasa kurang puas dengan pelayanan pengambilan obat di depo farmasi 1 karena kurangnya pegawai, sehingga kami harus nunggu+- 1 jam lebih. Kami mohon pelayanan yg cepet dan memuaskan,ttd ach muchlis. ". Kemudian lakukan proses preprocessing, teks berubah menjadi "keluarga pasien puas layan ambil obat depo farmasi kurang pegawai nunggu jam layan cepat puas muchlis ". Menentukan koefisien kontrol $\mu=0,1$, $\lambda=0,3$, threshold dan modifikasi rumus. Menghitung nilai 
prior probability naive bayes rumus no 1 terhadap semua kelas, diperoleh hasil $\mathrm{P}($ Class=loket pembayaran $)=68 / 1574=$ 0.0432 .

Menghitung nilai probabilitas Two Stage Smoothing setiap kata terhadap semua kelas, maka hasil yang diperoleh adalah $\mathrm{P} \lambda \mu($ word $=$ keluarga $\mid$ class $=$ tidak terklasifikasi $)=0.0019$. Kemudian menghitung nilai probabilitas setiap kelas, maka diperoleh hasil $\mathrm{P}(\mathrm{D} \mid$ rawat inap $)=3,7107067445934 \mathrm{E}-50$. Lakukan normalisasi hasilnya $\mathrm{P}($ Class=tidak terklasifikasi $)=$ 1.5870950299765E-14. Urutkan nilai probabilitas kelas dari tertinggi hingga terendah dan ambil 2 nilai probabilitas tertinggi, diperoleh kelas Farmasi=54455863,6174 dan Rawat Jalan= 1,6049. Periksalah nilai probabilitas tertinggi ke 2 untuk menentukan hasil klasifikasi.

Proses disinilah yang membedakan hasil output klasifikasinya. Hal ini dilakukan untuk mengetahui apakah outputnya memiliki satau atau dua kelas. Jika nilai probabilitas lebih besar dari threshold maka output single kelas, tetapi jika nilainya lebih kecil dari dari threshold maka outputnya multi kelas. Dari contoh diatas nilai probabilitas rawat jalan adalah 1,6049045186192E-8 sedangkan thresholdnya 0,6 maka hasilnya satu kelas, artinya Rawat Jalan bukan bagian dari kelas pertama. Kesimpulan dari hasil klasifikasi teks diatas adalah Farmasi.

Aplikasi yang dirancang menunjukkan hasil perhitungan dengan menggunakan threshold statis dan threshold dinamis. Threshold statis bersifat tidak berubah untuk setiap teks yang diklasifikasikan berdasarkan metode NBTS. Sedangkan threshold dinamis [13], [14] bersifat selalu berubah secara otomatis untuk setiap teks yang diklasifikasikan berdasarkan nilai NBTS dengan menghitung jarak rata-rata yang paling dominan terhadap nilai NB tertinggi pertama.

\section{Algoritma 2. Multi Klasifikasi Threshold Dinamis}

[Fungsi : klasifikasi multi kelas dinamis]

[input : nilai probabilitas semua kelas ]

[output : hasil klasifikasi]

1: Hitung rata2 nilai probabilitas $\mathrm{NB}+$ Smoothing setiap teks.

2: Ambil nilai rata2 sebagai nilai threshold dinamis.

3: Ambil 2 nilai probabilitas tertinggi.

4: Bandingkan nilai probabilitas tertinggi ke 2 dengan nilai threshold.

5: Tampilkan hasil klasifikasi nilai probabilitas ke-1 dan ke-2 jika ada.

Contoh SMS dengan menggunakan algoritma 2, dengan teks awal "perawat cuek, kurang ramah pelayanan lebih diperbaiki lagi khususnya untuk perawat harus lebih perhatikan kondisi dan kebutuhan pasien.”. Kemudian lakukan proses pre-processing, teks berubah menjadi "perawat cuek ramah layan baik awat hati kondisi pasien". Menentukan Koefisien control nilai $\mu=0,2$ dan $\lambda=2000$. Mencari nilai probabilitas naive bayes setiap kelasnya, diperoleh $\mathrm{P}($ Class=profesi $)=0.1910$. Menghitung nilai probabilitas setiap kata hasil stemming terhadap masing-masing kelas misalnya kata "ramah", maka diperoleh P $\lambda \mu$ (word=ramah | class=tidak terklasifikasi) $=0.0042$. Menghitung nilai probalitas seluruh kelas terhadap setiap kata misalnya klasifikasi Profesi, P(D|profesi $)=2,0220$ E-20. Normalisasi menjadi $\mathrm{P}($ Class $=$ profesi $)=1.5870$. Urutkan nilai probabilitas kelas dari tertinggi hingga terendah dan ambil 2 nilai probabilitas tertinggi, maka hasilnya kelas Rawat Inap $=1,4361$ dan profesi $=0,4647$. Periksalah nilai probabilitas tertinggi ke 2 untuk menentukan hasil klasifikasi.

Proses disinilah yang membedakan hasil output klasifikasinya. Nilai threshold disetiap data uji nilainya akan selalu berubah tergantung pada nilai probabilitasnya, maka rata-rata nilai probabilitas $=0,4995$. Jadikan nilai nilai rata-rata sebagai nilai threshold dinamis. Ambil 2 nilai probabilitas tertinggi, maka diperoleh klasifikasi 1 adalah Rawat Inap dengan nilai 1,4361 dan klasifikasi ke 2 adalah Profesi dengan nilai 0,4647. Bandingkan nilai probabilitas tertinggi ke 2 dengan threshold. Karena nilai probabilitas kelas Profesi lebih kecil dari nilai threshold maka kelas tersebut bagian dari kelas pertama atau output dari hasil klasifikasi ini adalah multi kelas. Berdasarkan hasil perhitungan sebelumnya, disimpulkan hasil klasifikasinya adalah Rawat Inap dan Profesi.

Proses awal aplikasi ini dimulai dari melakukan pelabelan manual terhadap data SMS mentah sesuai dengan daftar kelas yang telah ditentukan dan dilanjutkan dengan proses preprocessing dari data SMS yang sudah berlabel. Hasil dari tahap pre-processing kemudian lakukan pengaturan data training dan data testingnya dipilah berdasarkan persentase $20-50 \%$ untuk dilakukan proses uji coba klasifikasi menggunakan NBTS. Hasilnya dievaluasi untuk mengetahui dan membandingkan tingkat akurasi pada proses klasifikasi. Setelah proses pengujian dan evaluasi selesai maka dihitung jumlah kelas terbesar akan mendapatkan rekomendasi berupa surat teguran mengenai pelayanan yang diberikan terhadap masyarakat. Setiap SMS baru yang dikirimkan oleh masyarakat akan dilakukan pre-processing dan dilakukan pengklasifikasian dengan menggunakan data training yang didapatkan dari seluruh data SMS hasil pre-processing dengan menggunakan Nä̈ve Bayes dan TS Smoothing [9]. Hasil klasifikasi SMS baru digukan untuk meneruskan pesan secara otomatis dari masyarakat kepada penanggung jawab setiap unit yang berkaitan berdasarkan isi SMS yang telah diklasifikasi.

\section{HASIL EKSPERIMEN}

Sebelum melakukan uji coba klasifikasi, yang harus dilakukan adalah memilah data SMS dan responden menjadi data training dan data testing. Pemilihan ini dilakukan 4 variasi data testing berdasarkan presentase 20\%, 30\%, 40\%, dan $50 \%$ dari keseluruhan data. Pemilihan data testing ini dilakukan secara acak berdasarkan indeknya (kode teks). Untuk setiap pemilihan tersebut dilakukan uji coba klasifikasi menggunakan NBTS. Pemilahan data testing dan data training dalam sistem ditunjukkan pada Tabel 1. 


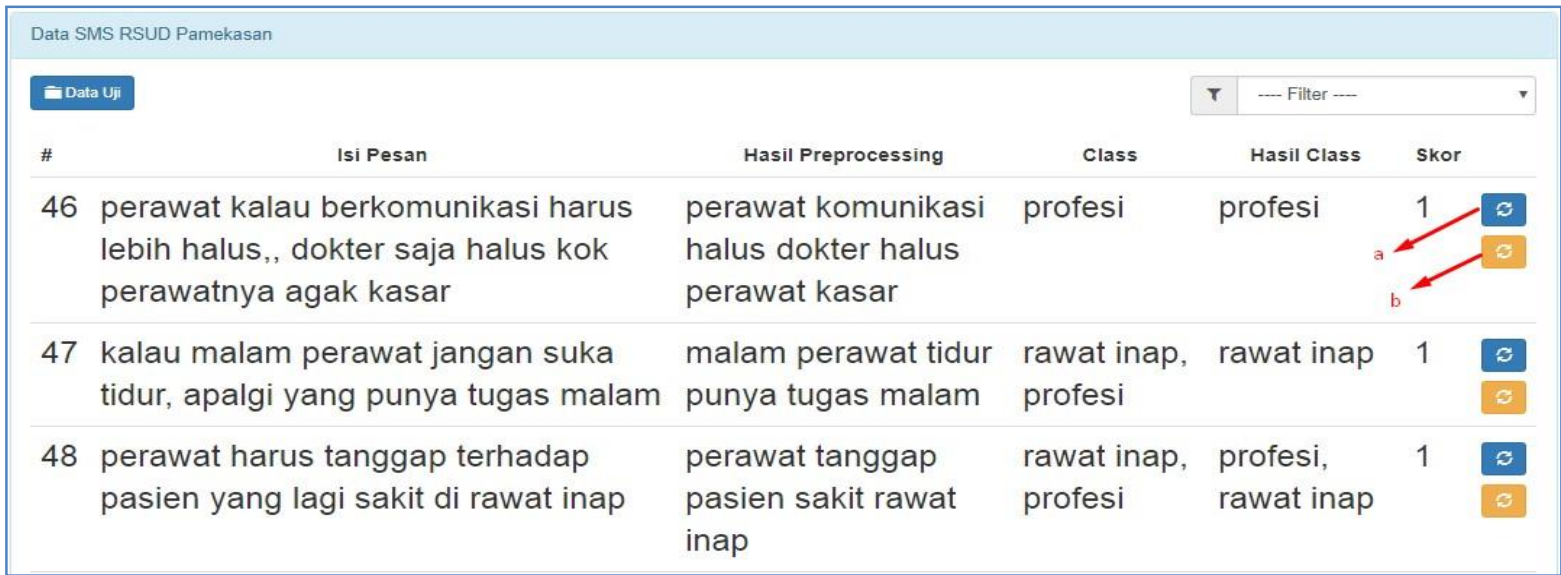

Gambar 4. Hasil Klasifikasi Data Testing

TABEL I

DATA TESTING DAN DATA TRAINING

\begin{tabular}{ccccc}
\hline \hline No & $\begin{array}{c}\text { Persentase } \\
\text { Data Testing }(\%)\end{array}$ & $\begin{array}{c}\text { Jumlah } \\
\text { Data }\end{array}$ & $\begin{array}{c}\text { Data } \\
\text { Testing }\end{array}$ & $\begin{array}{c}\text { Data } \\
\text { Training }\end{array}$ \\
\hline 1 & 20 & 2292 & 458 & 1834 \\
2 & 30 & 2292 & 682 & 1610 \\
3 & 40 & 2292 & 912 & 1380 \\
4 & 50 & 2292 & 1143 & 1149 \\
\hline \hline
\end{tabular}

Pada Tabel 1 pemilahan data testing dan data training dilakukan secara dinamis dengan memilih kode teks dalam database. Hal ini dilakukan agar dimungkinkan untuk menambah variasi pemilihan data testing dan data training, dengan ketentuan lebih banyak data training dari pada testing.

TABEL II

UJI COBA KLASIFIKASI THRESHOLD STATIS

\begin{tabular}{ccccccc}
\hline \hline No & $\begin{array}{c}\text { Data } \\
\text { uji }\end{array}$ & $\lambda$ & $\mu$ & Threshold & Akurasi & Rata2 \\
\hline 1 & 458 & 0,2 & 2000 & 3 & $85,22 \%$ & \\
2 & 458 & 0,2 & 0,5 & 3 & $81,25 \%$ & \\
3 & 458 & 0,3 & 1000 & 2 & $84,56 \%$ & \\
4 & 458 & 0,2 & 0,5 & 2 & $80,14 \%$ & $82,79 \%$ \\
\hline 5 & 682 & 0,2 & 2000 & 3 & $85,48 \%$ & \\
6 & 682 & 0,2 & 0,5 & 3 & $82,11 \%$ & \\
7 & 682 & 0,3 & 1000 & 2 & $83,28 \%$ & \\
8 & 682 & 0,2 & 0,5 & 2 & $81,23 \%$ & $83,03 \%$ \\
\hline 9 & 912 & 0,2 & 2000 & 3 & $86,73 \%$ & \\
10 & 912 & 0,2 & 0,5 & 3 & $82,02 \%$ & \\
11 & 912 & 0,3 & 1000 & 2 & $85,09 \%$ & \\
12 & 912 & 0,2 & 0,5 & 2 & $80,70 \%$ & $83,64 \%$ \\
\hline 13 & 1143 & 0,2 & 2000 & 3 & $85,91 \%$ & \\
14 & 1143 & 0,2 & 0,5 & 3 & $80,66 \%$ & \\
15 & 1143 & 0,3 & 1000 & 2 & $83,55 \%$ & \\
16 & 1143 & 0,2 & 0,5 & 2 & $79,70 \%$ & $82,46 \%$ \\
\hline
\end{tabular}

Pada Tabel 2 menunjukkan hasil uji coba klasifikasi menggunakan metode NBTS dengan pengaturan threshold statis. Koefisien lamda, miu dan threshold disesuaikan nilainya untuk mendapatkan nilai akurasi yang tinggi, pada beberapa percobaan akan diambil akurasi yang tertinggi di setiap presentase data testing, dalam hal ini no uji coba ke 1, 5, 9 dan 13 adalah hasil akurasi tertinggi.

Pada Tabel 3 menunjukkan hasil uji coba klasifikasi menggunakan metode NBTS dengan pengaturan threshold dinamis. Pada Tabel 2 kolom threshold bernilai 0 artinya nilai ini memiliki nilai threshold yang selalu berubah tergantung nilai probabilitas masing-masing teks yang akan diklasifikasikan.

TABEL III

UJI COBA KLASIFIKASI THRESHOLD DINAMIS

\begin{tabular}{ccccccc}
\hline \hline No & $\begin{array}{c}\text { Data } \\
\text { uji }\end{array}$ & $\lambda$ & $\mu$ & Threshold & Akurasi & Rata2 \\
\hline 1 & 458 & 0,1 & 3000 & 0 & $77,49 \%$ & \\
2 & 458 & 0,2 & 900 & 0 & $76,61 \%$ & \\
3 & 458 & 0,1 & 0,3 & 0 & $74,83 \%$ & \\
4 & 458 & 0,2 & 0,3 & 0 & $75,07 \%$ & $76,00 \%$ \\
\hline 5 & 682 & 0,1 & 3000 & 0 & $80,06 \%$ & \\
6 & 682 & 0,2 & 900 & 0 & $76,98 \%$ & \\
7 & 682 & 0,1 & 0,3 & 0 & $76,25 \%$ & \\
8 & 682 & 0,2 & 0,3 & 0 & $76,10 \%$ & $77,35 \%$ \\
\hline 9 & 912 & 0,1 & 3000 & 0 & $80,59 \%$ & \\
10 & 912 & 0,2 & 900 & 0 & $78,95 \%$ & \\
11 & 912 & 0,1 & 0,3 & 0 & $76,21 \%$ & \\
12 & 912 & 0,2 & 0,3 & 0 & $76,21 \%$ & $77,99 \%$ \\
\hline 13 & 1143 & 0,1 & 3000 & 0 & $77,87 \%$ & \\
14 & 1143 & 0,2 & 900 & 0 & $77,17 \%$ & \\
15 & 1143 & 0,1 & 0,3 & 0 & $74,28 \%$ & \\
16 & 1143 & 0,2 & 0,3 & 0 & $74,72 \%$ & $76,01 \%$ \\
\hline \multicolumn{7}{c}{} \\
\hline \hline
\end{tabular}

Pada Gambar 4 hasil klasifikasi data testing menunjukkan isi Pesan merupakan field untuk menampung isi pesan, hasil dari proses pre-processing di tampilkan pada kolom hasil prepropessing, proses pelabelan yang dilakukan oleh pakar hasilnya ditunjukkan pada kolom Class sedangkan hasil proses dari perhitungan klasifikasi multi kelas ditunjukkan pada kolom Hasil Class, kemudian hasil proses scoring ditunjukkan pada Skor. Pada pojok kanan atas juga disediakan filter yang berfungsi untuk menampilkan hasil klasifikasi berdasarkan seluruh data atau berdasarkan multi label-nya atau berdasarkan hasil multi klasifikasi-nya. Ada dua tombol proses yaitu tombol a untuk melihat detil perhitungan proses klasifikasi NBTS dan tombol b untuk melihat hasil detil perhitungan proses SCORING NBTS.

Pada Gambar 5 disajikan contoh SMS baru yang telah diklasifikasikan menggunakan NBTS. Fitur ini akan digunakan setelah dilakukan sinkronisasi antara aplikasi ini dengan Aplikasi SMS Center RSUD yang sudah ada sebelumnya ditampilkan sebelah kanan berupa tabel statistik hasil klasifikasi dari data SMS berupa presentase masing-masing kelas dan tampak sebelah kiri ada grafik pie yang 
menggambarkan luasan persentase kelas yang ada. Terdapat skoring tertinggi yang mendapatkan SMS terbanyak dan skor berdasarkan tingkat keluhan, sehingga dalam hal ini bisa direkomendasikan mendapatkan surat peringatan terhadap penanggung jawab Rawat Jalan.
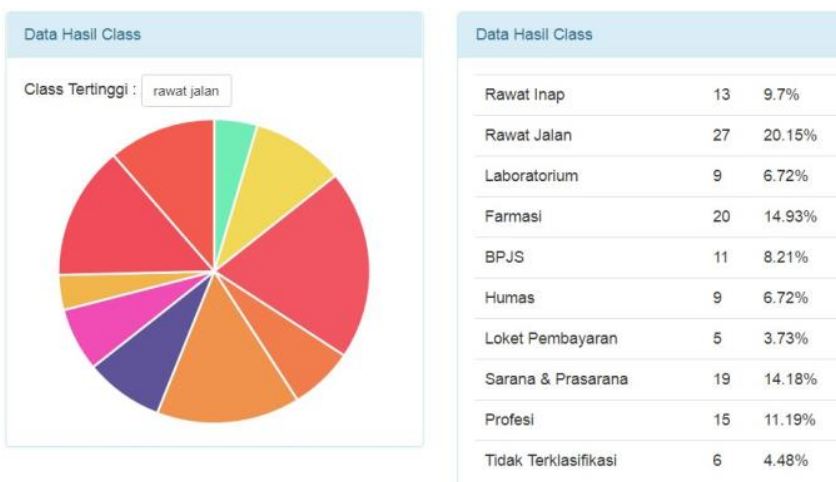

Gambar 5. Grafik hasil Klasifikasi SMS baru

Informasi kelas tertinggi yang terletak di atas gambar grafik, juga berfungsi untuk mencetak surat peringatan terhadap penanggung jawab unit berdasarkan hasil skoring terbesar yang diperoleh dari rata rata jumlah klasifikasi ditambah total skor masing-masing SMS.

TABEL IV

ANALISA AKURASI UJI COBA KLASIFIKASI

\begin{tabular}{ccccccc}
\hline \hline No & Threshold & 1 & 2 & 3 & 4 & $\begin{array}{c}\text { Rerata } \\
(\%)\end{array}$ \\
\hline 1 & Manual & $82,78 \%$ & $83,03 \%$ & $83,64 \%$ & $82,46 \%$ & $82,97 \%$ \\
2 & Dinamis & $75,99 \%$ & $77,35 \%$ & $77,99 \%$ & $76,01 \%$ & $76,84 \%$ \\
& & & & & Selisih & $6,14 \%$ \\
\hline \hline
\end{tabular}

Pada Tabel 4 dapat diketahui rata-rata akurasi uji coba klasifikasi menggunakan Nä̈ve Bayes dengan TS Smoothing menggunakan threshold Statis(Manual) 82,97\%, sedangkan rata-rata akurasi uji coba klasifikasi menggunakan Nä̈ve Bayes dengan TS-Smoothing menggunakan threshold Dinamis sebesar 76,84\%. Terbukti klasifikasi menggunakan NBTS threshold Statis dapat meningkatkan akurasi klasifikasi sebesar 6,14\% apabila dibandingkan dengan klasifikasi NBTS menggunakan threshold Dinamis. Besar kecilnya akurasi klasifikasi sangat dipengaruhi oleh terjadinya kesalahan klasifikasi.

TABEL V

STATISTIK DATA UjI COBA KLASIFIKASI

\begin{tabular}{clc}
\hline \hline \multirow{2}{*}{ No } & \multicolumn{1}{c}{ Class } & Jumlah Data Testing \\
\hline 1 & Rawat Inap & 122 \\
2 & Rawat Jalan & 74 \\
3 & Laboratorium & 8 \\
4 & Farmasi & 35 \\
5 & BPJS & 36 \\
6 & Humas & 67 \\
7 & Loket Pembayaran & 25 \\
8 & Sarana dan Prasarana & 172 \\
9 & Profesi & 116 \\
10 & Tidak Terklasifikasi & 27 \\
\hline \hline
\end{tabular}

TABEL VI

STATISTIK DATA Uji CoBa KLASIFIKASI

\begin{tabular}{clcc}
\hline \hline \multirow{2}{*}{ No } & Medode NBTS & Klasifikasi Benar & Klasifikasi Salah \\
\hline 1 & Threshold statis & 583 & 99 \\
2 & Threshold dinamis & 546 & 136 \\
\hline \hline
\end{tabular}

Uji coba klasifikasi dilakukan dengan data latih $30 \%$ dari total data sms dan responden sebesar 682 data testing pada Tabel 1 nomor 2. Pemilahan data testing dilakukan secara dinamis oleh sistem dengan cara mengambil kode teks secara acak pada masing-masing kelas sebesar 30\%. Statistik jumlah data testing bisa dilihat pada Tabel 5. Selisih Jumlah data testing antar kelas sangat besar atau tidak seimbang, sehingga berpengaruh pada hasil uji coba klasifikasi lihat Tabel 6, hasil klasifikasi salah semakin besar.

Pada Tabel 7 bagian ini akan dipaparkan hasil uji metode dari semua smoothing yang ada. Tahap pengujian ini menggunakan data testing baru sebesar $20 \%$ dari keseluruhan data.

TABEL VII

AKURASI SEMUA SMOOTHING

\begin{tabular}{llccc}
\hline \hline No & \multicolumn{1}{c}{ Smoothing } & $\begin{array}{c}\text { Koefisien } \\
\text { Kontrol }\end{array}$ & Threshold & $\begin{array}{c}\text { Akurasi } \\
(\%)\end{array}$ \\
\hline 1 & Laplace & - & 2 & 85.65 \\
2 & Jelinek-Mercer(JM) & $\lambda=0.1$ & 2 & 86,75 \\
3 & Dirichlet (DIR) & $\mu=0.1$ & 2 & 88,30 \\
4 & Absolute Discounting (DS) & $\delta=0.1$ & 2 & 83,22 \\
5 & Two Stage (TS) & $\lambda=0.1, \mu=3000$ & 0 & 88,52 \\
\hline \hline
\end{tabular}

Berdasarkan hasil uji coba bisa disimpulkan Laplace smoothing, Dir Smoothing, JM Smoothing dan AD smoothing akurasinya masih dibawah TS-Smoothing.

\section{KESIMPULAN}

Adapun beberapa kesimpulan yang didapatkan dalam penelitian ini, antara lain:

1. Penelitian ini telah berhasil mengklasifikasikan dokumen dalam bentuk teks dengan baik menggunakan metode naive bayes dengan TS-Smoothing.

2. Pada penelitian ini rata-rata akurasi klasifikasi dengan menggunakan Nä̈ve Bayes TS-Smoothing dan threshold Statis sebesar 82,97\%, sedangkan rata-rata akurasi klasifikasi dengan threshold Dinamis sebesar 76,84\%. Maka Nä̈ve Bayes dengan TS-Smoothing mampu untuk memecahkan permasalahan pada multi klasifikasi.

3. Metode Two Stage Smoothing dengan threshold statis terbukti meningkatkan akurasi klasifikasi sebesar 6,14\%.

4. Pada uji coba klasifikasi threshold statis diperoleh pengujian akurasi terendah sebesar $80,13 \%$ dan akurasi terttinggi sebesar $86,73 \%$.

5. Pada uji coba klasifikasi threshold dinamis diperoleh pengujian akurasi terendah sebesar $74,28 \%$ dan akurasi tertinggi sebesar $80,59 \%$.

6. Rekomendasi surat evaluasi internal diberikan kepada unit dengan skoring terbesar, tidak hanya berdasarkan jumlah SMS yang diterima di setiap unit. 
7. Kesalahan klasifikasi sering disebabkan oleh tidak seimbangnya jumlah SMS di setiap kelas pada data training.

8. TS-Smoothing lebih baik dari segi akurasi dibandingkan dengan metode yang lainnya.

\section{DAFTAR PUSTAKA}

[1] G. Malik, M. Tarique,“On Machine Learning Techniques For Multi-class Classification",International Journal of Advancements in Research \& Technology, vol.3, no.2, Feb2 014.

[2] R. Adipratama, R.A. Hendrawan, R.P. Kusumawardani,"Klasifikasi SMS Pada Sistem Support Ticket Pengaduan Pelanggan Dengan Menggunakan Metode Naïve Bayes", Undergraduate Thesis of Information System: ITS Library,2011.

[3] Badar Said, Yuliana Melita P,"Klasifikasi Data SMS Center Bupati Pamekasan Menggunakan Naïve Bayes Dengan Mad Smoothing”,In IdeaTech,pp.92-99,2015.

[4] Q Yuan, G Cong, N.M. Thalmann,"Enhancing naive bayes with various smoothing methods for short text classification," in WWW 12 Companion, ed. New York: ACM,2012,pp.645-646.

[5] Shruti Aggarwal, Devinder Kaur, "Naïve Bayes Classifier with Various Smoothing Techniques for Text Documents", IJCTT.2013.

[6] D.D. Arifin, Shaufiah, M.A. Bijaksana,"SMS Filtering Menggunakan Naive Bayes Classifier dan FP-Growth Algorithm Frequent Itemset", eProceeding of Engineering,vol.2,no.2, agustus 2015.

[7] Afrianto, Kurniawati."Kategorisasi Dokumen Teks secara Multi Label Menggunakan Fuzzy C-Means dan K-Nearest Neighbors pada Artikel Berbahasa Indonesia".JUTI.2013.

[8] Tsoumakas,G.,\&Katakis,I,"Multilabel classification: An overview", International Journal of Data Warehousing and Mining, vol.3,no.3,pp. $1-13.2007$.

[9] Zhihua Wei, Hongyun Zhang, Zhifei Zhang, Wen Li, Duoqian Miao. "A Naive Bayesian Multi-label Classication Algorithm With Application to Visualize Text Search Results". International Journal of Advanced Intelligence,vol.3, No.2, pp. 173-188, July 2011.

[10]R. K. Hapsari, Y. J. Santoso,"Stemming Artikel Berbahasa Indonesia dengan Pendekatan Confix-stripping", in Prosiding Seminar Nasional Manajemen Teknologi XXII, ed.Surabaya:Program Studi MMTITS,pp.251-258,Jan 2015.

[11]M.K. Dalal, M.A. Zaveri,"Automatic Text Classification: A Technical Review", International Journal of Computer Applications.vol.28,pp.09758887,Agst.2011.

[12] Gilang Jalu Selo W.T, Budi Susanto, Rosa Delima, "Implementasi Naïve Bayesian Classifier Untuk Kasus Filtering SMS Spam“, Informatika.2013.

[13] Arifin, A.Z., I.P.A.K. Mahendra dan H.T. Ciptaningtyas, "Enhanced Confix Stripping Stemmer and Ants Algorithm for Classifying News Document in Indonesian Language". ICTS. 2009.

[14] Karl-Michael Schneider, Techniques for Improving the Performance of Naive Bayes for Text Classification, citeseerx, 2005.

Sholeh Rachmatullah lahir di kota Pamekasan, Jawa Timur, pada tahun 1985. Menyelesaikan studi S1 di program studi Teknik Informatika Universitas Trunojo pada tahun 2007. Sholeh menyelesaikan studi masternya pada jurusan Pasca Sarjana Teknologi Informasi STTS pada tahun 2017. Sekarang sebagai Dosen program studi Teknik Informatika Univeritas Madura. Minat penelitian adalah data mining, rekayasa perangkat lunak dan sistem informasi.

Reddy Alexandro Harianto lahir di Surabaya, Jawa Timur, Indonesia, pada tahun 1989. Dia menyelesaikan studi S1 di program studi Teknik Informatika Sekolah Tinggi Teknik Surabaya pada tahun 2011, dan menyelesaikan studi masternya pada jurusan Teknologi Informatika di Institut Teknologi Sepuluh Nopember Surabaya pada tahun 2015.
Minat penelitiannya adalah bidang Artificial Intelligence, Computer Vision, Data Mining. 